\title{
ANALISIS HUKUM PENERAPAN ANTI PENCUCIAN UANG TERHADAP KEBIJAKAN RAHASIA BANK
}

\author{
Ilmi Vediani \\ email: vediani@yahoo.com
}

\begin{abstract}
This article discusses money laundering and the implementation of Customer Due Diligence (CDD) which is to be understood as part of the effort to eradicate this particular crime. Money laundering is not an autonomous crime but is always related or stems from an original crime (predicate crime). This crime is committed habitually using financial institution or banks as its instrument. One factor making this possible is the obligation of bank to guard and maintain customer's trust by virtue of bank's secrecy. Nonetheless, this bank secrecy can be waived. By virtue of CDD, banks are under the obligation to implement a process of customer identification, including verification- monitoring of customers financial transaction or activities. In the case, they detect suspicious financial transactions the banks are under the obligation to report their findings to the Indonesian Financial Transaction Reports and Analysis Centre (INTRAC) and/or law enforcement officers
\end{abstract}

Keywords: money laundering, bank, customer due diligence, anti-money laundering program and bank secrecy

\begin{abstract}
Abstrak
Tulisan ini akan menelaah persoalan tindak pidana pencucian uang dan penerapan Customer Due Diligence ( $C D D$ ) sebagai program pencegahan dan pemberantasannya. Pencucian uang merupakan perbuatan tindak pidana turunan (proceed of crime) dari tindak pidana asal (predicate crime), yang banyak menggunakan media lembaga keuangan dalam hal ini bank sebagai sarana untuk melakukan proses pencucian uang. Satu faktor yang memungkinkan terjadinya tindak pidana pencucian uang ialah karena bank sebagai lembaga keuangan yang berbasis kepercayaan memberikan jaminan kerahasiaan atas data nasabah sebagai rahasia bank. Namun kerahasiaan ini, dapat dibongkar melalui penerapan CDD sebagai bagian dari program anti pencucian uang (Program APU). Melalui CDD, bank diwajibkan melakukan serangkaian proses yang terdiri dari identifikasi, verifikasi, pemantauan terhadap data nasabah dan transaksi keuangan nasabah secara berlanjut, terrmasuk pelaporan kepada pihak yang berwenang, yaitu Pusat Pelaporan dan Analisis Transaksi Keuangan (PPATK) dan aparat penegak hukum apabila ada transaksi keuangan nasabah yang mencurigakan.
\end{abstract}

Kata Kunci:

pencucian uang, bank, customer due diligence, program anti pencucian uang dan rahasia bank

\section{Pendahuluan}

Pencucian uang adalah suatu tindak kejahatan serius, di mana pelaku kejahatan mengubah hasil kejahatannya untuk mengelabui asal usul harta hasil kejahatan. Secara sederhana, pencucian uang merupakan tindak pidana turunan 
(proceed of crime) dari tindak pidana asal (predicate crime). Tindak pidana asal (predicate crime) yang dimaksud dapat berupa tindak pidana korupsi, tindak pidana terorisme, tindak pidana narkotika, tindak pidana perjudian, tindak pidana di bidang perbankan dan lainnya. Hal ini sesuai dengan pendapat yang dikemukakan oleh Sarah N. Welling sebagaimana dikutip oleh Adrian Sutedi bahwa pencucian uang dimulai dengan adanya uang haram atau uang kotor (dirty money). Uang dapat menjadi kotor dengan dua cara, pertama, melalui pengelakan pajak (tax evasion), yaitu memperoleh uang secara legal, tetapi jumlah yang dilaporkan kepada pemerintah untuk keperluan perhitungan pajak lebih sedikit daripada yang sebenarnya diperoleh. Kedua, memperoleh uang melalui cara-cara yang melanggar hukum. ${ }^{1}$ Dalam ketentuan mengenai pencucian uang antara hasil tindak pidana (proceed of crime) dengan tindak pidana asal (predicate crimes) dijadikan satu ketentuan karena memang terkait sangat erat. ${ }^{2}$

Istilah pencucian uang telah dikenal sejak tahun 1930 di Amerika Serikat, yaitu ketika mafia membeli perusahaan yang sah dan resmi sebagai salah satu strateginya. Investasi terbesar adalah perusahaan pencucian pakaian atau disebut laundromats yang ketika itu terkenal di Amerika Serikat. Usaha pencucian pakaian ini berkembang maju dan berbagai perolehan uang hasil kejahatan seperti dari cabang usaha lainya ditanamkan ke perusahaan pencucian pakaian ini, seperti uang hasil minuman keras ilegal, hasil perjudian dan hasil usaha pelacuran. ${ }^{3}$

Pengertian pencucian uang di Indonesia sebagaimana diatur dalam Pasal 1 angka 1 Undang-Undang Nomor 25 Tahun 2003 tentang Perubahan Atas UndangUndang Nomor 15 Tahun 2002 Tentang Tindak Pidana Pencucian Uang adalah: "perbuatan menempatkan, mentransfer, membayarkan, membelanjakan, menghibahkan, menyumbangkan, menitipkan, membawa ke luar negeri, menukarkan, atau perbuatan lainnya atas Harta Kekayaan yang diketahuinya atau patut diduga merupakan hasil

1 Adrian Sutedi, Hukum PerBankan Suatu Tinjauan Pencucian Uang, Merger, Likuidasi, Dan Kepailitan, Sinar Grafika, Jakarta, 2010, hlm., 17.

2 Ni Komang Wiska Ati Sukariyani, Tinjauan Umum Mengenai Pencucian Uang, http:// www.scribd.com/doc/75635799/Tinjauan Umum-Mengenai-Pencucian-Uang. 21.

${ }_{3}^{3}$ Adrian Sutedi, Tindak Pidana Pencucian Uang, Citra Aditya Bakti, Bandung, 2008, hlm., 1. 
tindak pidana dengan maksud untuk menyembunyikan, atau menyamarkan asal usul Harta Kekayaan sehingga seolah-olah menjadi Harta Kekayaan yang sah"

Terdapat 3 (tiga) tahapan dalam pelaksanaan tindak pencucian uang, yaitu: 4

1. Tahap penempatan (placement);

Pada tahap penempatan dana ini (placement), uang hasil kejahatan ditempatkan pada bank tertentu yang dianggap aman. Penempatan uang tersebut dimasukkan hanya untuk sementara waktu saja. Dalam tahap penempatan dana ini juga dilakukan proses membenam uang (immersion);

2. Tahap pelapisan (layering);

Dalam tahap pelapisan ini, dilakukan kegiatan-kegiatan yang bertujuan untuk menghilangkan jejak atau indikasi asal usul uang tersebut. Dalam tahap membenamkan uang ini, uang tersebut benar-benar dipulihkan/dicuci untuk menghilangkan jejak uang tersebut.;

3. Tahap menggunakan harta kekayaan atau uang (intergration);

Dalam tahap integrasi dan repartasi ini uang hasil kejahatan yang telah dicuci pada tahap pembenanam tersebut dikumpulkan kembali ke dalam suatu proses keuangan yang sah.

Perbuatan tindak pidana pencucian uang dapat menimbulkan dampak yang sangat besar terhadap perkembangan sektor perekonomian dan bisnis, sebagaimana yang dikemukakan oleh John McDowell dan Gary Novis bahwa dampak tindak pidana pencucian uang tersebut adalah sebagai berikut: ${ }^{5}$

1. Merusak sektor bisnis swasta yang sah (undermining the legitimate private bussines sector);

\footnotetext{
${ }^{4}$ Munir Fuady, Bisnis Kotor Anatomi Kejahatan Kerah Putih, Citra Aditya Bakti, Bandung, hlm., 87.

${ }^{5}$ John McDowell (Senior Policy Adviser, Bureau of International Narcotics and Law Enforcement Affairs, U.S. Department of State) Gary Novis (Program Analyst, Bureau of International Narcotics and Law Enforcement Affairs, U.S. Department of State), The Consequences Of Money Laundering And Financial Crime, http://www.usteas.gov.
} 
2. Merusak integritas pasar-pasar keuangan (undermining the integrity of financial market);

3. Hilangnya kendali pemerintah terhadap kebijakan ekonomi (loss of control of economic policy);

4. Distorsi dan ketidakstabilan ekonomi (economic distortion and instability);

5. Hilangnya pendapatan negara (loss of revenue);

6. Resiko dalam usaha-usaha privatisasi oleh pemerintahan suatu negara (risks to privatization efforts);

7. Resiko rusaknya reputasi negara (reputation risk);

Media yang digunakan untuk melakukan tindak pidana pencucian uang adalah lembaga jasa keuangan, seperti bank, perusahaan asuransi, sekuritas dan sebagainya serta dapat melalui media seperti perusahaan properti, industri hiburan, dan sebagainya. Yang paling banyak digunakan adalah melalui media bank. Tindak pidana pencucian uang merupakan bagian dari tindak pidana di bidang ekonomi. Pelaku tindak pidana ekonomi, pada umumnya mereka yang mempunyai status sosial menengah ke atas dalam masyarakat, bersikap dan bertingkah laku seperti intelektual, yang lazimnya dikenal dengan istilah "white collar crime" (pelaku tindak pidana kerah putih), misalnya pelaku ini menggunakan bank untuk memutihkan keuntungan yang diperoleh dari tindak pidana. ${ }^{6}$ Banyaknya tindak pidana pencucian uang melalui bank, dikarenakan melalui bank, uang yang diperoleh dari tindak pidana kejahatan (tindak pidana asal) dapat dikelola melalui berbagai jenis produk yang disediakan oleh bank tersebut dengan proses transaksi yang relatif cepat bahkan dapat dilakukan antar kota maupun antar negara.

Bank dalam melakukan kegiatannya yang berupa menghimpun dana dan menyalurkan dana berdasarkan kepada prinsip-prinsip perbankan, yaitu:

1. Prinsip kepercayaan (fiduciary relation principle);

2. Prinsip kehati-hatian (prudential principle);

${ }^{6}$ Marulak Pardede, Hukum Pidana Bank, Pustaka Sinar Harapan, Jakarta, 1995, hlm., 123. 
3. Prinsip kerahasiaan (secrecy principle);

4. Prinsip mengenal nasabah (know your customer principle).

Pelaku tindak pidana pencucian uang melakukan tindak kejahatannya dengan memilih bank sebagai media kejahatannya karena uang yang dimilikinya disimpan di bank dengan jaminan kerahasiaan yang diberikan oleh bank atas data dirinya maupun simpanannya. Oleh karenanya kegiatan bank sangat rentan akan tindak kejahatan termasuk tindak pidana pencucian uang. Bank sangat rentan terhadap reputasi resiko karena ia merupakan target atau sarana utama bagi aktivitas kejahatan yang dapat dilakukan nasabah. ${ }^{7}$

Latar belakang terjadinya tindak pidana pencucian uang di Indonesia, didasarkan pada 3 (tiga) alasan yaitu: ${ }^{8}$

1. Di Indonesia berlaku ketentuan bahwa uang yang disimpan dalam bentuk deposito berjangka tidak diusut asal-usulnya sehingga dengan sendirinya diputihkan dan halal;

2. Undang-Undang Perbankan yang berlaku di Indonesia memberikan peluang besar kepada bank untuk merahasiakan kekayaan seseorang;

3. Indonesia menganut sistem devisa bebas. Dalam sistem ini setiap orang yang pergi keluar negeri dan masuk ke Indonesia dapat dengan leluasa membawa uang dalam jumlah yang tidak dibatasi sehingga setiap orang dimungkinkan mentransfer uang simpanannya kemana saja dan dapat menerima uang kiriman dari luar negeri berapapun jumlahnya.

Untuk menghindari dan mencegah digunakannya bank sebagai media tindak pidana pencucian uang, maka selain dengan menerapkan prinsip kehatihatian (prudential principle) dalam melaksanakan kegiatan usahanya, bank pun perlu untuk menerapkan prinsip mengenal nasabah (know your customer principle) kepada setiap nasabah yang menggunakan jasanya. Prinsip mengenal nasabah (know your customer principle) merupakan bagian dari program anti

\footnotetext{
${ }^{7}$ Basel Comitee On Banking Supervision, Customer Due Dilligence For Bank, 4 Oktober 2011.

8 Pande Radja Silalahi, Pencucian Uang dan Sistem Keuangan Internasional, Hukum Bisnis, 1998, hlm., 3, 22, dan 25,
} 
pencucian uang yang dikenal dengan sebutan program APU, yang mengadopsi rekomendasi standar internasional yaitu Rekomendasi $40+9$ FATF, yang dikeluarkan oleh The Financial Action Task Force on Money Laundering (FATF).

Di Indonesia, prinsip mengenal nasabah (know your customer principle) diatur dalam Peraturan Bank Indonesia (PBI) Nomor 3/10/PBI/2001 tentang Penerapan Prinsip Mengenal Nasabah (know your customer principles) dan sejak berlakunya PBI tersebut maka mulai diterapkannya regulasi Anti Pencucian Uang pada industri perbankan. Penerapan Prinsip Mengenal Nasabah (know your customer principle) dilakukan sebagai dampak dari dimasukkannya Indonesia ke dalam negara-negara yang digolongkan sebagai NCCT's (Non Cooperative Country and Territories) oleh Financial Action Task Force (FATF), dikarenakan Indonesia tidak mempunyai :

1. Undang Undang dan Peraturan mengenai Tindak Pidana Pencucian Uang (TPPU);

2. Lembaga yang berwenang di dalam penanganan TPPU/Financial Intelligent Unit;

3. Kerjasama dengan Lembaga Internasional di dalam Penanganan TPPU.

Penggolongan Indonesia ke dalam NCCT's (Non Cooperative Country and Territories) tidak dapat dibiarkan saja, karena akan menimbulkan dampak berupa:

1. Indonesia akan dikategorikan sebagai negara berisiko tinggi;

2. Perdagangan internasional akan terhambat dan biayanya akan menjadi sangat mahal, terkait korespondensi dengan industri perbankan luar negeri.

Pada saat ini, Prinsip Mengenal Nasabah (know your customer principles) lebih dikenal dengan sebutan Customer Due Diligence (CDD).

Dalam prakteknya penerapan Customer Due Diligence (CDD) yang merupakan bagian dari program anti pencucian uang (Program APU) di bank tidaklah semudah yang dibayangkan, sehubungan dengan semakin maju dan canggihnya teknologi layanan yang disediakan bank sehingga menyulitkan untuk mendeteksi apakah aliran uang yang masuk atau ada di bank tersebut merupakan 
hasil tindak pidana pencucian uang atau bukan, ditambah pula dengan jaminan kerahasiaan yang diberikan oleh bank yang dikenal sebagai industri keuangan yang berbasis kepercayaan.

Berdasarkan pemaparan di atas, maka penulis akan membahas permasalahan tentang, penerapan Customer Due Diligence (CDD) dalam mengindentifikasi telah terjadinya tindak pidana pencucian uang di bank, dan penerapan Customer Due Diligence (CDD) sebagai bagian dari program anti pencucian uang (program APU) di bank dihadapkan dengan kebijakan prinsip kerahasiaan bank.

\section{Penerapan Prinsip Customer Due Diligence (CDD) sebagai bagian dari Program Anti Pencucian Uang (Program APU) di Bank}

Program Anti Pencucian Uang (Program APU) di industri perbankan dilakukan dengan cara menerapkan Prinsip Mengenal Nasabah (know your customer principle), yang pada tahun 2009 istilah Prinsip tersebut diganti dengan istilah Customer Due Diligence (CDD) sehubungan dengan digantinya Peraturan Bank Indonesia Nomor 3/10/PBI/2001 tentang Penerapan Prinsip Mengenal Nasabah dengan Peraturan Bank Indonesia Nomor 11/28/PBI/2009 tentang Penerapan Program Anti Pencucian Uang Dan Pencegahan Pendanaan Terorisme Bagi Bank Umum. Pada tahun 2012, Peraturan Bank Indonesia Nomor 11/28/PBI/2009 tentang Penerapan Program Anti Pencucian Uang Dan Pencegahan Pendanaan Terorisme Bagi Bank Umum tersebut diganti dengan Peraturan Bank Indonesia Nomor 14/27/PBI/2012 tentang Penerapan Program Anti Pencucian Uang Dan Pencegahan Pendanaan Terorisme Bagi Bank Umum.

Dalam Pasal 1 angka 7 dan Pasal 10 Peraturan Bank Indonesia Nomor 14/27/PBI/2012 tentang Penerapan Program Anti Pencucian Uang Dan Pencegahan Pendanaan Terorisme Bagi Bank Umum disebutkan bahwa Customer Due Diligence (CDD) merupakan kegiatan berupa identifikasi, verifikasi dan pemantauan yang dilakukan oleh Bank untuk memastikan bahwa suatu transaksi 
yang dilakukan telah sesuai dengan profil calon nasabah, Walk In Customer atau nasabah, yang wajib dilakukan pada saat:

1. Melakukan hubungan usaha dengan calon Nasabah;

2. Melakukan hubungan usaha dengan Walk In Customer;

3. Bank meragukan kebenaran informasi yang diberikan oleh nasabah, penerima kuasa, dan/atau Beneficial Owner;

4. Terdapat transaksi keuangan yang tidak wajar yang terkait dengan pencucian uang dan/atau pendanaan terorisme.

Dapat disimpulkan bahwa penerapan Customer Due Diligence (CDD) dilakukan secara berkesinambungan yang dimulai dari awal menjadi nasabah yaitu pada tahap pembukaan rekening dan dilakukan terus menerus selama menjadi nasabah di bank tersebut.

Dalam proses Customer Due Diligence (CDD), bank wajib untuk mengelompokkan nasabahnya sesuai dengan tingkat resiko terjadinya pencucian uang berdasarkan analisis terhadap identitas, lokasi usaha bagi nasabah perusahaan, profil nasabah, jumlah transaksi, kegiatan usaha nasabah, struktur kepemilikan bagi nasabah perusahaan dan informasi lainnya yang dapat digunakan untuk mengukur tingkat risiko Nasabah, sebagaimana diatur dalam Pasal 11 Peraturan Bank Indonesia Nomor 14/27/PBI/2012 tentang Penerapan Program Anti Pencucian Uang Dan Pencegahan Pendanaan Terorisme bagi Bank Umum.

Untuk mewujudkan pencegahan terjadinya tindak pidana pencucian uang di bank, profil nasabah merupakan salah satu dari informasi yang diperlukan dalam penerapan Customer Due Diligence (CDD). Berdasarkan Pasal 14 Peraturan Bank Indonesia Nomor 14/27/PBI/2012 tentang Penerapan Program Anti Pencucian Uang Dan Pencegahan Pendanaan Terorisme Bagi Bank Umum, profil nasabah yang diperlukan antara lain adalah identitas nasabah, sumber dana, maksud dan tujuan hubungan usaha atau transaksi yang akan dilakukan dan sebagainya, yang dapat dibuktikan dengan dokumen-dokumen pendukung. 
Dokumen pendukung tersebut wajib diteliti dan diverifikasi oleh bank berdasarkan dokumen dan atau sumber informasi lainnya yang dapat dipercaya dan independen sebagaimana diatur dalam Pasal 22 Peraturan Bank Indonesia Nomor 14/27/PBI/2012 tentang Penerapan Program Anti Pencucian Uang Dan Pencegahan Pendanaan Terorisme Bagi Bank Umum.

Manfaat dengan diterapkannya prinsip Customer Due Diligence (CDD) di bank adalah bank diharapkan dapat memperoleh informasi secara detail mengenai calon nasabah, mengenal nasabah dan memahami transaksi yang dilakukan nasabah, mengetahui transaksi nasabah yang tidak normal atau mencurigakan, melindungi reputasi dan integritas bank, memfasilitasi kepatuhan terhadap ketentuan, melindungi bank dari ancaman eksternal yaitu digunakan sebagai sarana pencucian uang atau sasaran kejahatan.

Kriteria transaksi-transaksi keuangan yang mencurigakan sebagaimana diatur dalam Pasal 1 angka 5 Undang-Undang No 8 Tahun 2010 tentang Pencegahan dan Pemberantasan Tindak Pidana Pencucian Uang adalah:

a. Transaksi Keuangan yang menyimpang dari profil, karakteristik, atau kebiasaan pola transaksi dari pengguna jasa yang bersangkutan;

b. Transaksi Keuangan oleh pengguna jasa yang patut diduga dilakukan dengan tujuan untuk menghindari pelaporan transaksi yang bersangkutan yang wajib dilakukan oleh pihak pelapor sesuai dengan ketentuan Undang-Undang ini;

c. Transaksi keuangan yang dilakukan atau batal dilakukan dengan menggunakan Harta Kekayaan yang diduga berasal dari hasil tindak pidana; atau

d. Transkasi keuangan yang diminta oleh PPATK untuk dilaporkan oleh Pihak pelapor karena melibatkan harta kekayaan yang diduga berasal dari hasil tindak pidana."

Atas transaksi-transaksi keuangan yang mencurigakan tersebut, bank wajib untuk melakukan pengkinian dokumen identitas nasabah dan analisis serta pemantauan secara berkesinambungan antara transaksi keuangan yang dilakukan nasabah dengan profil nasabah. Hal-hal tersebut dilakukan untuk memastikan 
apakah transaksi yang mencurigakan tersebut merupakan suatu transaksi keuangan dari kegiatan pencucian uang.

Sedangkan nasabah bank yang dapat dikategorikan sebagai pelaku tindak pidana pencucian uang adalah:

1. Setiap orang yang menempatkan, mentransfer, mengalihkan, membelanjakan, membayarkan, menghibahkan, menitipkan, membawa ke luar negeri, mengubah bentuk, menukarkan dengan mata uang atau surat berharga atau perbuatan lain atas harta kekayaan yang diketahuinya atau patut diduganya merupakan hasil tindak pidana dengan tujuan menyembunyikan atau menyamarkan asal usul harta kekayaannya tersebut. ${ }^{9}$

2. Setiap orang yang menyembunyikan atau menyamarkan asal usul, sumber, lokasi, peruntukan, pengalihan hak-hak, atau kepemilikan yang sebenarnya atas harta kekayaan yang diketahuinya atau patut diduganya merupakan hasil tindak pidana. ${ }^{10}$

3. Setiap orang yang menerima atau menguasai penempatan, pentransferan, pembayaran, hibah, sumbangan, penitipan, penukaran, atau menggunakan harta kekayaan yang diketahuinya atau patut diduganya merupakan hasil tindak pidana. ${ }^{11}$

Pengertian orang di atas adalah orang perseorangan atau korporasi, jadi pelaku tindak pidana pencucian uang bukan hanya manusia sebagai individu tetapi juga bisa badan usaha. Khusus untuk kategori pelaku tindak pidana pencucian uang nomor 3 (tiga) di atas, dikecualikan bagi pelapor adanya transaksi yang mencurigakan berupa tindak pidana pencucian uang dan pihak bank termasuk ke dalam pelapor yang dimaksud.

Oleh karenanya apabila terjadi suatu transaksi keuangan yang mencurigakan yang dilakukan oleh nasabah bank, maka menurut Pasal 48 ayat (1) Peraturan Bank Indonesia Nomor 14/27/PBI/2012 tentang Penerapan

\footnotetext{
9 Pasal 3 Undang-Undang Nomor 8 Tahun 2010 tentang Pencegahan dan Pemberantasan Tindak Pidanan Pencucian Uang

10 Id., Pasal 4.

11 Id., Pasal 5.
} 
Program Anti Pencucian Uang Dan Pencegahan Pendanaan Terorisme Bagi Bank Umum, pihak bank memiliki kewajiban untuk melaporkan transaksi tersebut sebagai laporan transaksi keuangan yang mencurigakan yang ditujukan kepada Pusat Pelaporan dan Analisis Transaksi Keuangan (PPATK) yang merupakan suatu lembaga independen yang bertanggungjawab terhadap Presiden Republik Indonesia, yang dibentuk dalam rangka untuk memberantas pencucian uang di Indonesia dan sebagai pemenuhan Pasal 16 The Forty Recommendations yang dibuat oleh Financial Action Task Force On Money Laundering (FATF). Pihak bank pun berkewajiban untuk melakukan kerjasama dengan penegak hukum maupun otoritas yang berwenang, sebagaimana diatur dalam Pasal 51 Peraturan Bank Indonesia Nomor 14/27/PBI/2012 tentang Penerapan Program Anti Pencucian Uang Dan Pencegahan Pendanaan Terorisme Bagi Bank Umum. Apabila Bank tidak mau melakukan kerjasama dengan penegak hukum maupun otoritas yang berwenang, maka bank dapat dikenakan sanksi administratif berupa teguran tertulis, penurunan dalam penilaian tingkat kesehatan, pembekuan kegiatan usaha tertentu, pemberhentian pengurus bank dan pencantuman anggota Direksi dan anggota Dewan Komisaris, pegawai bank, pemegang saham dalam daftar orang tercela dibidang Perbankan.

Dalam Pasal 72 ayat 1 Undang-Undang No 8 tahun 2010 tentang Pencegahan Dan Pemberantasan Tindak Pidana Pencucian Uang disebutkan bahwa:

“Untuk kepentingan pemeriksaan dalam perkara tindak pidana pencucian uang, penyidik, penuntut umum, atau hakim berwenang meminta Pihak Pelapor untuk memberikan keterangan secara tertulis mengenai Harta Kekayaan dari:

a. orang yang telah dilaporkan oleh PPATK kepada penyidik;

b. tersangka; atau

c. terdakwa.

Pihak Pelapor di sini adalah termasuk pihak bank, yang memiliki data atas nasabahnya termasuk data kekayaan nasabahnya dan dengan proses Customer 
Due Diligence (CDD) akan membantu untuk menentukan apakah harta kekayaan tersebut dapat dikategorikan sebagai hasil dari tindak pidana pencucian uang.

Untuk tindak pidana pencucian uang yang masuk dalam kategori memiliki resiko tinggi, maka pihak bank memiliki kewajiban untuk menerapkan Customer Due Diligence (CDD) yang lebih mendalam, yang dikenal dengan sebutan Enhanced Due Dilligence (EDD). Yang dimaksud dengan Enhanced Due Dilligence (EDD) sebagaimana diatur dalam Pasal 1 angka 8 Peraturan Bank Indonesia Nomor 14/27/PBI/2012 tentang Penerapan Program Pencucian Uang Dan Pencegahan Pendanaan Terorisme bagi Bank Umum adalah:

"Enhanced Due Dilligence atau yang selanjutnya disebut sebagai EDD adalah tindakan CDD lebih mendalam yang dilakukan Bank pada saat berhubungan dengan Calon Nasabah, WIC, atau Nasabah yang tergolong berisiko tinggi, termasuk Politically Exposed Person, terhadap kemungkinan pencucian uang dan pendanaan terorisme."

Salah satu cara untuk mendeteksi lebih dini melalui prinsip mengenal nasabah atau Customer Due Diligence (CDD) adalah: ${ }^{12}$

1. Melakukan tatap muka;

2. Meminta informasi nasabah;

3. Identifikasi transaksi nasabah;

4. Melaporkan transaksi nasabah;

5. Prosedur penerapan prinsip mengenal nasabah selalu mengikuti perkembangan;

6. Memiliki standar dan prosedur tersendiri;

7. Teknologi;

8. Pengawasan dan pengendalian internal independen;

9. Pelatihan yang cukup.

Peraturan Bank Indonesia Nomor 14/27/PBI/2012 tentang Penerapan Program Pencucian Uang Dan Pencegahan Pendanaan Terorisme Bagi Bank

12 Daniel Hendrawan, Prinsip Mengenal Nasabah Dan Tindak Pidana Pencucian Uang Dalam Pasar Modal dalam buku Problematika Menciptakan Iklim Usaha Yang Kondusif, Komisi Hukum Nasional RI, Jakarta, 2011, hlm., 70-72. 
Umum tidak hanya mengatur mengenai tindak pidana pencucian uang saja, tetapi juga mengatur mengenai tindak pidana pendanaan terorisme. Keduanya saling terkait, perbedaannya hanya terletak pada:

1. Pada pencucian uang, uang yang diperoleh berasal atau hasil dari kegiatan yang tidak sah, yang dikenal dengan sebutan tindak pidana asal (predicate crime), sedangkan pada pendanaan terorisme, uang yang diperoleh bisa berasal dari kegiatan yang sah atau tidak sah yaitu hasil dari tindak pidana;

2. Pencucian uang bertujuan untuk menyamarkan seakan-akan uang yang diperoleh tersebut merupakan hasil kegiatan yang sah, sedangkan pada pendanaan terorisme uang yang diperoleh digunakan untuk mendukung kegiatan terorisme.

Baik pencucian uang maupun pendanaan terorisme seringkali menggunakan media bank dan oleh karena untuk menghindarkan dari penggunaan bank untuk tujuan kejahatan, maka pihak bank wajib menerapkan prinsip Customer Due Diligence (CDD) kepada setiap nasabahnya.

\section{Kebijakan Kerahasiaan Bank}

Asas rahasia (konfidensialitas) dalam bidang keuangan pada lembaga keuangan perbankan sudah dikenal sejak lama. Pada zaman pertengahan ketentuan semacam itu telah diatur pada peraturan perundang-undangan, bahkan di kerajaan Jerman pada saat itu telah diatur dalam Kitab Undang-Undang Hukum Perdata. Dengan berkembangnya perdagangan dan runtuhnya feodalisme dalam pertarungan yang semakin sengit untuk memperjuangkan hak-hak individu, kepercayaan kepada kebijaksanaan lembaga perbankan untuk merahasiakan keterangan-keterangan mengenai soal-soal keuangan, dan pribadi nasabahnasabahnya menjadi suatu kebutuhan yang tidak bisa ditawar-tawar lagi bagi perlindungan hak milik pribadi dan bagi kelangsungan praktek perdagangan. Menjelang pertengahan abad ke-19, boleh dikatakan semua pemerintahan di Eropa Barat telah mensahkan asas kerahasiaan perbankan, dan semenjak itu 
undang-undang serupa telah diberlakukan di setiap negara yang menghendaki sistem perbankan yang tertib. ${ }^{13}$

Bank merupakan suatu lembaga keuangan yang menjalankan usahanya berdasarkan kepercayaan dari nasabahnya sehingga bank dituntut untuk dapat menjaga kerahasiaan atas segala data dan informasi yang terkait dengan nasabahnya termasuk informasi transaksi keuangan yang dilakukan nasabahnya.

Pengertian rahasia bank sebagaimana diatur dalam pasal 1, angka 28, Undang-Undang No. 10 Tahun 1998 tentang Perubahan Atas Undang-Undang No. 7 Tahun 1992 tentang Perbankan adalah:

"Rahasia bank adalah segala sesuatu yang berhubungan dengan keterangan mengenai nasabah penyimpan dan simpanannya."

Bank memiliki kewajiban untuk menjamin kerahasiaan bank tersebut, sebagaimana diatur dalam Pasal 40 ayat (1) Undang-Undang No. 10 Tahun 1998 tentang Perubahan Atas Undang-Undang No. 7 Tahun 1992 tentang Perbankan. Ketentuan rahasia bank diperlukan karena perbankan harus melindungi nasabahnya. ${ }^{14}$

Berdasarkan ketentuan tentang kewajiban bank atas kerahasiaan mengenai nasabah penyimpan dan simpanannya, maka kewajiban tersebut tidak hanya meliputi kerahasiaan mengenai transaksi keuangan nasabah tetapi juga meliputi data pribadi nasabah yang bersangkutan. Apabila nasabah bank tersebut adalah nasabah penyimpan yang sekaligus juga sebagai nasabah debitur, bank wajib merahasiakan keterangan tentang nasabah dalam kedudukannya sebagai nasabah penyimpan. Keterangan mengenai nasabah selain sebagai nasabah penyimpan, bukan merupakan keterangan yang wajib dirahasiakan bank. ${ }^{15}$ Walaupun bukan merupakan keterangan yang wajib dirahasiakan, bukan berarti keterangan mengenai nasabah debitur bank menjadi keterangan yang bebas untuk

\footnotetext{
13 Muhamad Djumhana, Rahasia Bank, Citra Aditya Bakti, Bandung, 1996, hlm., 112.

14 Id, hlm., 115.

15 Yunus Husein, Rahasia Bank Dan Penegakan Hukum, Pustaka Juanda Tiga Lima, Jakarta, 2010, hlm., 96.
} 
diinformasikan ke siapa pun. Apabila bank tidak merahasiakan keterangan tentang debiturnya tidak tertutup kemungkinan bank digugat oleh nasabahnya secara perdata dengan dengan alasan cidera janji (wanprestasi) atau perbuatan melawan hukum. Bank dapat dianggap cidera janji apabila kewajiban merahasiakan itu terdapat di dalam perjanjian antara bank dan nasabah baik eksplisit maupun implisit. ${ }^{6}$ Apabila tidak ada perjanjian, kewajiban bank mempertahankan rahasia bank didasarkan pada peraturan perundang-undangan atau konsep hukum lainnya, seperti konsep perbuatan melawan hukum. Artinya dalam hal bank memberikan keterangan tentang nasabahnya yang merugikan nasabah, bank dapat dituntut oleh nasabahnya dengan alasan perbuatan melawan hukum. ${ }^{17}$

Jaminan kerahasiaan yang diberikan oleh Bank kepada nasabahnya, juga diatur dalam Pasal 2, Peraturan Otoritas Jasa Keuangan No. 1/POJK.07/2013 Tentang Perlindungan Konsumen Sektor Jasa Keuangan, menerapkan prinsip:

a. transparansi;

b. perlakuan yang adil;

c. keandalan;

d. kerahasiaan dan keamanan data/informasi Konsumen; dan

e. penanganan pengaduan serta penyelesaian sengketa Konsumen secara sederhana, cepat, dan biaya terjangkau.

Pelaku jasa keuangan di atas termasuk pihak bank dan yang termasuk konsumen dalam peraturan otoritas jasa keuangan tersebut adalah nasabah pada perbankan.

Tinjauan teori tentang rahasia bank, menunjukkan ada dua pendapat yaitu: 18

1. Teori rahasia bank bersifat mutlak, yaitu bahwa bank berkewajiban menyimpan rahasia nasabah yang diketahui oleh bank karena kegiatan usahanya dalam keadaan apapun, biasa atau dalam keadaan luar biasa. Semua keterangan mengenai nasabah dan keuangannya yang tercatat di bank wajib

\footnotetext{
16 Id, hlm., 100-101.

17 Id, hlm., 61

18 Supra no. 13, hlm., 116-117
} 
dirahasiakan tanpa pengecualian dan pembatasan dengan alasan apa pun dan oleh siapapun, kerahasiaan mengenai nasabah dan keuangannya tidak boleh dibuka (diungkapkan). Apabila terjadi pelanggaran terhadap kerahasiaan tersebut, bank yang bersangkutan harus bertanggungjawab atas segala akibat yang ditimbulkannya. ${ }^{19}$ Teori ini terlalu individualistis, bahkan sebenarnya bertentangan dengan kepentingan umum. Tidak dapat diterima adanya suatu "secret absolute", meskipun itu di lingkungan pekerjaan kepercayaan seperti kalangan kedokteran dan perbankan;

2. Teori yang kedua adalah rahasia bank bersifat nisbi, yaitu bahwa bank diperbolehkan membuka rahasia nasabahnya, untuk suatu kepentingan mendesak, misalnya demi kepentingan negara atau untuk kepentingan umum. Teori ini disebut juga dengan teori rahasia bank bersifat relatif. Keberatan terhadap teori ini adalah rahasia bank masih dapat dijadikan perlindungan bagi pemilik dana yang tidak halal, yang kebetulan tidak terjangkau oleh aparat penegak hukum karena tidak terkena penyidikan. Dengan demikian dananya tetap aman. ${ }^{20}$

Teori rahasia bank bersifat nisbi atau relatif dalam penerapannya akan berdasarkan pada asas proposional khususnya berkaitan dengan pembukaan rahasia bank. Asas proposional menghendaki pertimbangan kepentingan mana yang lebih berat, yaitu tidak membuka rahasia yang berarti menyimpan rahasia untuk kepentingan terbatas yaitu kalangan perbankan, atau membuka rahasia demi kepentingan yang lebih besar yaitu kepentingan negara. ${ }^{21}$

Penentuan hal-hal yang termasuk kategori rahasia bank harus berpijak pada:22

1. Kelaziman operasional perbankan;

19 Seri Hukum Bisnis. Rahasia Bank, https://yessymsari.wordpress.com/2012/11/29/rahasiabank-2/

20 Id

21 Supra no. 13, hlm., 117.

22 Id, hlm., 121-122 
2. Apakah pembocoran/pembukaan informasi akan merugikan pemilik informasi (nasabah) atau menguntungkan pihak lain;

3. Pihak pemilik informasi (nasabah) harus yakin secara wajar bahwa informasi itu benar-benar belum diketahui masyarakat luas.

Walaupun peraturan perbankan di Indonesia memberikan jaminan kerahasiaan terhadap nasabahnya, akan tetapi Undang-Undang No. 10 Tahun 1998 tentang Perubahan Atas Undang-Undang No. 7 Tahun 1992 tentang Perbankan mengatur pengecualian terhadap penerapan kebijakan kerahasiaan bank yaitu untuk kepentingan umum, yang terdiri dari:

1. Perpajakan (Pasal 41 ayat (1));

2. Penyelesaian piutang bank yang sudah diserahkan kepada Badan Urusan Piutang dan Lelang Negara/Panitia Urusan Piutang Negara (Pasal 41A ayat (1));

3. Peradilan dalam perkara pidana (Pasal 42 ayat (1));

4. Perkara perdata antara bank dan nasabahnya (Pasal 43);

5. Tukar menukar informasi antar bank (Pasal 44 ayat (1));

6. Permintaan, persetujuan atau kuasa dari nasabah penyimpan yang dibuat secara tertulis (Pasal 44A ayat (1));

7. Permintaan ahli waris yang sah dari nasabah penyimpan yang telah meninggal dunia (Pasal 44A ayat 2).

Pengecualian terhadap penerapan kebijakan kerahasiaan Bank juga diatur dalam Pasal 31 ayat (2) Peraturan Otoritas Jasa Keuangan No. 1/POJK.07/2013 tentang Perlindungan Konsumen Sektor Jasa Keuangan, yang berbunyi:

"(2) Larangan sebagaimana dimaksud pada ayat (1) dikecualikan dalam hal:
a. Konsumen memberikan persetujuan tertulis; dan/atau
b. diwajibkan oleh peraturan perundang-undangan. 


\section{Analisa Hukum Penerapan Anti Pencucian Uang Terhadap Kebijakan Rahasia Bank}

Prinsip Customer Due Diligence (CDD) sebagai salah satu program Anti Pencucian Uang (Program APU) melakukan identifikasi terhadap data nasabah dan menganalisa transaksi keuangan nasabah yang didukung dengan dokumendokumen terkait, untuk mengantisipasi digunakannya media bank sebagai sarana kejahatan yaitu antara lain pencucian uang. Dengan melakukan tahapan-tahapan tersebut diharapkan bank dapat mengenal lebih jauh nasabahnya. Proses Customer Due Diligence (CDD) di bank terhadap nasabah dilakukan terusmenerus, tidak hanya pada saat menjadi calon nasabah karena proses Customer Due Diligence (CDD) tidak hanya untuk mengetahui identitas pribadi nasabah tetapi ditujukan juga untuk dapat mengamati transaksi keuangan nasabahnya baik saat yang bersangkutan mengirimkan uang maupun menerima uang di rekeningnya. Sehingga apabila ditemukan ketidaksesuaian antara profil nasabah dengan transaksi keuangan di rekeningnya atau transaksi keuangan di rekeningnya dicurigai sebagai hasil dari tindak pidana, maka transaksi tersebut dapat dianggap sebagai transaksi keuangan yang mencurigakan dan pihak bank memiliki kewajiban untuk melaporkannya kepada Pusat Pelaporan dan Analisis Transaksi Keuangan (PPATK), yang oleh Pusat Pelaporan dan Analisis Transaksi Keuangan (PPATK) akan diteruskan untuk dilaporkan kepada penyidik, jaksa dan hakim. Maka peran aktif bank, Pusat Pelaporan dan Analisis Transaksi Keuangan (PPATK) serta aparat penegak hukum sangat dibutuhkan, karena apabila dari pihak bank tidak teliti dan tidak aktif dalam menerapkan prinsip Customer Due Diligence (CDD) atau pihak Pusat Pelaporan dan Analisis Transaksi Keuangan (PPATK) atau aparat penegak hukum tidak menindaklanjuti pelaporan transaksi keuangan yang mencurigakan, maka uang hasil pencucian uang akan dengan mudah tersimpan di bank dan kemudian digunakan oleh nasabahnya. Bahkan untuk nasabah yang memiliki risiko tinggi untuk melakukan tindak pidana pencucian uang dapat diterapkan Enhanced Due Dilligence (EDD) yaitu Customer 
Due Diligence (CDD) yang lebih mendalam. Pelaksanaan prinsip Customer Due Diligence (CDD) dan prinsip Enhanced Due Dilligence (EDD) juga menjadi bagian dari pelaksanaan prinsip kehatian-hatian bank dalam menjalankan kegiatan usahanya untuk menjaga agar bank terhindar dari kegiatan kejahatan di bidang ekonomi.

Penerapan Customer Due Diligence (CDD) dalam mengindentifikasi dan menganalisa profil nasabah dan transaksi keuangannya sebagai transaksi keuangan yang mencurigakan terkait dengan 3 (tiga) kategori pelaku tindak pidana pencucian uang di bank yang telah dibahas di atas. Termasuk ke dalam kategori pelaku tindak pidana pencucian uang adalah pihak yang rekeningnya menerima aliran uang sebagaimana diatur dalam Pasal 5 Undang-Undang Nomor 8 Tahun 2010 tentang Pencegahan dan Pemberantasan Tindak Pidana Pencucian Uang. Dalam Undang-Undang tersebut hanya disebutkan, bahwa nasabah dapat dikategorikan sebagai pelaku tindak pidana pencucian uang apabila yang bersangkutan mengetahui atau patut diduga mengetahui bahwa uang yang ditransfer ke dalam rekeningnya tersebut berasal dari hasil tindak pidana. Sehingga dapat diasumsikan apabila penerima tersebut tidak mengetahui asal uang tersebut merupakan hasil dari tindak pidana, maka yang bersangkutan tidak dapat dianggap sebagai pelaku tindak pidana pencucian uang dan tidak dapat dikenakan sanksi pidana. Oleh karenanya akan timbul permasalahan dalam membuktikan penerima uang tersebut apakah mengetahui atau patut diduga mengetahui asal uang yang diterimanya, misalkan seorang isteri menerima uang dari suaminya setiap bulan dengan cara ditransfer ke rekening isterinya dan kemudian suami diduga melakukan tindak pidana pencucian uang dengan menyimpan uang hasil pencucian uangnya tersebut ke berbagai rekening termasuk rekening isterinya, di mana harus dibuktikan apakah isteri tersebut mengetahui atau patut diduga mengetahui asal uang yang ditransfer suaminya ke rekeningnya adalah hasil tindak pidana pencucian uang. Dalam penjelasan Pasal 5 
Undang-Undang Nomor 8 Tahun 2010 tentang Pencegahan Dan Pemberantasan Tindak Pidana Pencucian Uang dijelaskan mengenai definisi patut diduga, yaitu:

"Yang dimaksud dengan patut diduganya adalah suatu kondisi yang memenuhi setidak-tidaknya pengetahuan, keinginan, atau tujuan pada saat terjadinya Transaksi yang diketahuinya yang mengisyaratkan adanya pelanggaran hukum"

Oleh karenanya aparat hukum atau pihak yang berwenang wajib membuktikan adanya "pengetahuan" atau "keinginan" atau "tujuan" dari penerima uang, di mana 3 (tiga) hal tersebut merupakan pembuktian yang cukup sulit karena perlu ditentukan dasar ukuran seseorang dianggap memiliki pengetahuan dan adanya keinginan dari penerimaan uang tersebut.

Prinsip kerahasiaan bank menjadi salah satu alasan mengapa bank menjadi media tindak pidana pencucian uang, karena para pelaku tindak pidana pencucian uang mendapatkan rasa aman bahwa identitas dan transaksi keuangannya akan dijaga kerahasiaannya dari pihak ketiga, apalagi bila prinsip kerahasiaan yang diterapkan bank bersifat mutlak. Bahkan jaminan kerahasiaan bagi nasabah merupakan bagian dari jaminan perlindungan konsumen dan yang termasuk dalam pengertian konsumen tersebut adalah nasabah bank.

Apabila melihat pengertian rahasia bank dalam Pasal 1 angka 28 UndangUndang No. 10 Tahun 1998 tentang Perubahan Atas Undang-Undang Nomor 7 Tahun 1992 tentang Perbankan, yang dimaksud dengan "segala sesuatu" adalah segala informasi yang melekat pada nasabah tersebut seperti nama, alamat dan lainnya disamping informasi mengenai simpanannya. Informasi-informasi tersebut wajib dijaga kerahasiaannya oleh bank, akan tetapi apabila untuk kepentingan umum seperti perpajakan, penyelesaian piutang bank yang sudah diserahkan kepada Badan Urusan Piutang dan Lelang Negara/Panitia Urusan Piutang Negara, peradilan dalam perkara pidana, perkara perdata antara bank dan nasabahnya, tukar menukar informasi antar bank, permintaan atau persetujuan atau kuasa dari nasabah penyimpan yang dibuat secara tertulis dan permintaan ahli waris yang sah dari nasabah penyimpan yang telah meninggal 
dunia, maka informasi-informasi tersebut tidak lagi menjadi bagian dari rahasia bank. Dikesampingkannya kebijakan rahasia bank juga terlihat dalam Pasal 31 ayat (2) huruf b Peraturan Otoritas Jasa Keuangan No. 1/POJK.07/2013 tentang Perlindungan Konsumen Sektor Jasa Keuangan, di mana larangan untuk memberikan data atau informasi terkait konsumen (dalam hal ini nasabah) pelaku jasa keuangan (dalam hal ini bank) tidak berlaku dalam hal diwajibkan oleh Undang-Undang dan Undang-Undang yang dimaksud dapat merujuk kepada Undang-Undang Nomor 10 Tahun 1998 tentang Perubahan Atas Undang-Undang Nomor 7 Tahun 1992 tentang Perbankan.

Bank sebagai lembaga keuangan yang dipercaya oleh masyarakat (fiduciary financial institution) dihadapkan pada dua kewajiban yang saling bertentangan dan seringkali tidak dapat dirundingkan. Di satu pihak bank mempunyai kewajiban untuk tetap merahasiakan keadaan dan catatan keuangan nasabahnya (duty of confidentiality). Di lain pihak bank juga berkewajiban untuk mengungkapkan (disclose) keadaan dan catatan keuangan nasabahnya dalam keadaan-keadaan tertentu. ${ }^{23}$ Adanya kerahasiaan bank sering dijadikan oleh pelaku kejahatan keuangan untuk melakukan pemutihan uang atau pencucian uang dari uang hasil kejahatan menjadi uang yang bersih. Penerapan Customer Due Diligence (CDD) di bank memungkinkan dikesampingkannya prinsip kerahasiaan bank, yaitu dalam hal adanya kewajiban untuk memberitahukan informasi terkait nasabah dan transaksi keuangan yang mencurigakan kepada Pusat Pelaporan dan Analisis Transaksi Keuangan (PPATK) dan juga aparat penegak hukum.

Terkait untuk kepentingan peradilan dalam perkara pidana, sebagaimana diatur dalam Pasal 42 ayat 1 Undang-Undang No. 10 Tahun 1998 tentang Perubahan Atas Undang-Undang No. 7 Tahun 1992 tentang Perbankan, yang berbunyi:

"Untuk kepentingan peradilan dalam perkara pidana, Pimpinan Bank Indonesia dapat memberikan izin kepada polisi, jaksa, atau hakim

23 Id, hlm., 112-113. 
untuk memperoleh keterangan dari bank mengenai simpanan tersangka atau terdakwa pada bank."

Dapat disimpulkan bahwa untuk kepentingan peradilan dalam perkara tindak pidana pencucian uang dapat diberlakukan ketentuan pasal tersebut, sehingga keberlakuan prinsip kerahasiaan bank dapat dikesampingkan. Permasalahan akan timbul apabila uang hasil kejahatan tersebut disimpan di rekening yang bukan milik terdakwa atau tersangka, atau tersimpan di rekening keluarganya atau temannya (terdakwa atau tersangka menyebarkan uang hasil tindak pidana pencucian uang ke beberapa rekening), maka terhadap rekening tersebut akan berlaku prinsip rahasia bank dan akan menimbulkan kesulitan untuk membuka atas dasar kepentingan penyelidikan tindak pidana pencucian uang dan terhadap pemilik rekening tersebut akan bebas dari tuntutan tindak pidana pencucian uang. Padahal dalam pasal 5, Undang-Undang Nomor 8 Tahun 2010 tentang Pencegahan dan Pemberantasan Tindak Pidana Pencucian Uang, yang termasuk dalam kategori pelaku pencucian uang juga adalah orang yang menerima atau menguasai penempatan, pentransferan, pembayaran, hibah, sumbangan, penitipan, penukaran, atau menggunakan harta kekayaan yang diketahuinya atau patut diduganya merupakan hasil tindak pidana. Sehingga penerima uang hasil tindak pidana pencucian uang dapat ditetapkan menjadi tersangka atau terdakwa dan apabila terbukti yang bersangkutan mengetahui atau patut diduga mengetahui bahwa uang tersebut adalah hasil tindak pidana pencucian uang, maka yang bersangkutan dapat dikenakan sanksi pidana penjara dan denda.

Penerapan prinsip kerahasiaan di perbankan Indonesia dapat dikesampingkan untuk kepentingan umum antara lain untuk kepentingan perpajakan, peradilan dalam perkara pidana dan sebagainya sehingga penerapan prinsip kerahasiaan bank di Indonesia menganut sistem teori rahasia yang bersifat nisbi atau relatif. Hanya dalam ketentuan yang mengatur tentang pengecualian untuk berlakunya kerahasiaan bank, yaitu terhadap kepentingan umum, kurang begitu lengkap kategori yang masuk untuk kepentingan umumnya, 
dengan tidak dicantumkannya kewajiban untuk mencegah terjadinya tindak pidana (duty to the public to prevent fraud and crimes) ${ }^{24}$ sebagaimana telah diatur di Amerika Serikat dalam 12 USC section 3403 (c) dan untuk panggilan atau penggeledahan oleh pemerintah ${ }^{25}$ sebagaimana telah diatur di Amerika Serikat dalam Financial Privacy Act of 1978, 35 USC sec 3405. Padahal dengan dicantumkannya kewajiban untuk mencegah terjadinya tindak pidana (duty to the public to prevent fraud and crimes) dalam kategori kepentingan umum yang dapat mengkesampingkan prinsip rahasia bank, diharapkan dapat mencegah bank menjadi media tindak pidana pencucian uang. Yang membedakan dari kategori untuk kepentingan peradilan dalam perkara pidana adalah bahwa mengesampingkan prinsip rahasia bank untuk mencegah terjadinya tindak pidana berarti informasi terkait nasabah dan transaksi keuangannya dapat diberikan setiap saat dalam rangka mencegah terjadinya tindak pidana termasuk tindak pidana pencucian uang, sedangkan untuk kepetingan peradilan dalam perkara pidana informasi terkait nasabah dan transaksi keuangannya atau rahasia bank dapat dikesampingkan apabila masalah tindak pidana termasuk tindak pidana pencucian uang sudah masuk ke wilayah pengadilan.

\section{Penutup}

Tindak pidana pencucian uang banyak dilakukan melalui bank karena bank merupakan lembaga keuangan berbasis kepercayaan yang memberikan jaminan kerahasiaan atas data nasabah dan transaksi keuangan nasabah. 3 (tiga) tahapan dalam pelaksanaan tindak pencucian uang di bank adalah tahap penempatan (placement), tahap pelapisan (layering) dan tahap menggunakan harta kekayaan atau uang (intergration).

Program Anti Pencucian Uang (Program APU) di industri perbankan dilakukan dengan pelaksanaan prinsip Customer Due Diligence (CDD) yang sebelumnya dikenal dengan istilah prinsip Mengenal Nasabah (Know your

\footnotetext{
24 Supra no.15, hlm., 20.
}

25 Id. 
customer principle) yang mengadopsi rekomendasi standard internasional yaitu Rekomendasi 40 + 9 FATF, yang dikeluarkan oleh The Financial Action Task Force on Money Laundering (FATF).

Customer Due Diligence (CDD) dilakukan dengan cara mengidentifikasi, verifikasi dan pemantauan terhadap profil nasabah dan transaksi keuangannya yang dilakukan secara terus menerus sebagai upaya untuk mencegah atau mengetahui apabila telah terjadi pencucian uang oleh nasabahnya. Untuk nasabah bank yang memenuhi kriteria resiko tinggi akan terjadinya pencucian uang, maka akan diterapkan Enhanced Due Dilligence (EDD) yaitu Customer Due Diligence (CDD) yang lebih mendalam. Dalam proses Customer Due Diligence (CDD), pihak bank akan bekerjasama dengan Pusat Pelaporan dan Analisis Transaksi Keuangan (PPATK), aparat penegak hukum dan otoritas berwenang dalam bentuk pemberian informasi terkait nasabah dan transaksi keuangan nasabahnya. Hal ini seringkali menimbulkan dilema bagi bank sehubungan bank juga memiliki kewajiban untuk menerapkan prinsip kerahasiaan.

Perbankan Indonesia menganut teori rahasia yang bersifat nisbi atau relatif (tidak mutlak) sehingga terhadap penerapan prinsip kerahasiaan masih dapat dikesampingkan atau diterobos untuk hal-hal tententu, diantaranya untuk kepentingan umum, walaupun kriteria kepentingan umum yang diatur dalam Undang-Undang Perbankan masih dirasakan belum lengkap.

Terkait 3 (tiga) kategori pelaku tindak pidana pencucian uang sebagaimana yang diatur dalam Undang-Undang Nomor 8 Tahun 2010 tentang Pencegahan dan Pemberantasan Tindak Pidana Pencucian Uang, dalam rangka penyelidikan kasus tindak pidana pencuican uang masih menimbulkan permasalahan antara lain dalam menetapkan dasar ukuran seseorang dianggap mengetahui atau patut diduga mengetahui (memiliki pengetahuan, keinginan atau tujuan) penerimaan uang direkeningnya berasal dari hasil kejahatan, khususnya untuk kategori pelaku tindak pidana pencucian uang yang ke 3 (tiga) yaitu nasabah yang menerima transferan uang yang diduga hasil pencucian uang. 
Terkait ketentuan dalam Undang-Undang No. 10 Tahun 1998 tentang Perubahan Atas Undang-Undang No. 7 Tahun 1992 tentang Perbankan dapat dikesampingkannya rahasia bank untuk kepentingan peradilan dalam perkara pidana, pihak polisi, jaksa, atau hakim dapat meminta keterangan dari bank mengenai simpanan tersangka atau terdakwa pada bank. Hal ini menimbulkan permasalahan apabila uang hasil kejahatan tersebut disimpan di rekening yang bukan milik terdakwa atau tersangka akan tetapi tersimpan di rekening pihak lain, maka terhadap pemilik rekening tersebut akan tetap berlaku prinsip rahasia bank dan akan menimbulkan kendala bagi kepentingan penyelidikan tindak pidana pencucian uang dan terhadap pemilik rekening tersebut akan bebas dari tuntutan tindak pidana pencucian uang.

Dengan semakin meningkatnya kejahatan melaui bank khususnya pencucian uang, maka sangat diperlukan peran bank secara efektif dan teliti dalam menerapkan Customer Due Diligence (CDD) sebagai bagian dari program anti pencucian uang (Program APU), sehingga dapat mencegah atau meminimalisir terjadinya tindak pidana pencucian uang.

Perlu ditingkatkannya kesadaran masyarakat khususnya nasabah bank terkait pentingnya penerapan Customer Due Diligence (CDD) dalam pencegahan tindak pidana pencucian uang, sehingga diperlukan kesediaan dan kerjasama dari nasabah dalam memberikan selengkap-lengkapnya dan sebenar-benarnya kepada pihak bank terkait profil yang bersangkutan. Perlunya kesepakatan tertulis antara pihak bank dengan nasabah sehingga bank memiliki dasar (tidak hanya berdasarkan peraturan perundang-undangan) untuk memberikan informasi terkait nasabahnya kepada pihak ketiga antara lain Pusat Pelaporan dan Analisis Transaksi Keuangan (PPATK) dan aparat penegak hukum.

Ketentuan terkait rahasia bank untuk dapat dibuat dalam peraturan tersendiri dan tidak hanya menjadi bagian dari suatu undang-undang tentang perbankan, dengan tetap memperhatikan kepentingan dalam pencegahan kejahatan melalui media bank 
Kategori kepentingan umum yang dapat mengesampingkan berlakunya rahasia bank untuk dapat ditambah lagi, antara lain seperti yang sudah di lakukan di Amerika Serikat yaitu kewajiban untuk mencegah terjadinya tindak pidana, sehubungan dalam Undang-Undang No. 10 Tahun 1998 tentang Perubahan Atas Undang-Undang No. 7 Tahun 1992 tentang Perbankan, kepentingan umum yang dapat mengesampingkan prinsip rahasia bank adalah antara lain untuk kepentingan peradilan perkara tindak pidana, sehingga memiliki pengertian bahwa apabila belum menjadi perkara di peradilan maka tetap berlaku prinsip rahasia bank.

\section{Daftar Pustaka}

\section{Buku:}

Adrian Sutedi, Hukum Perbankan Suatu Tinjauan Pencucian Uang, Merger, Likuidasi, Dan Kepailitan, Sinar Grafika, Jakarta, 2010

Adrian Sutedi, Tindak Pidana Pencucian Uang, Citra Aditya Bakti, Bandung, 2008

Basel Comitee On Banking Supervision, Customer Due Dilligence For Bank, Oktober, 2011

Daniel Hendrawan, Prinsip Mengenal Nasabah Dan Tindak Pidana Pencucian Uang Dalam Pasar Modal dalam buku Problematika Menciptakan Iklim Usaha Yang Kondusif, Komisi Hukum Nasional RI, Jakarta, 201

Marulak Pardede, Hukum Pidana Bank, Pustaka Sinar Harapan, Jakarta,1995

Muhamad Djumhana, Rahasia Bank, Citra Aditya Bakti, Bandung, 1996

Munir Fuady, Bisnis Kotor Anatomi Kejahatan Kerah Putih, Citra Aditya Bakti, Bandung, 2004

Yunus Husein, Rahasia Bank Dan Penegakan Hukum, Pustaka Juanda Tiga Lima, Jakarta, 2010

\section{Jurnal:}

Pande Radja Silalahi, Pencucian Uang dan Sistem Keuangan Internasioanl, Volume 3 Jurnal Hukum Bisnis, Jakarta, 1998

\section{Internet:}

http://www.scribd.com/doc/75635799/TinjauanUmum-Mengenai-PencucianUang. 21.

http://www.usteas.gov

https://yessymsari.wordpress.com/2012/11/29/rahasia-bank-2/ 


\section{Perundang-Undangan:}

Undang-Undang RI., No. 10 Tahun 1998, Perubahan atas Undang-Undang No. 7 Tahun 1992 tentang Perbankan, L.N.R.I. Tahun 1998 No. 182

Undang-Undang RI., No. 8 Tahun 2010, Pencegahan dan Pemberantasan Tindak Pidana Pencucian Uang, L.N.R.I. Tahun 2010 No. 122

Peraturan Bank Indonesia., No. 14/27/PBI/2012, Penerapan Program Anti Pencucian Uang Dan Pencegahan Pendanaan Terorisme Bagi Bank Umum, L.N.R.I. Tahun 2012 No. 290

Peraturan Otoritas Jasa Keuangan, No. 1/POJK.07/2013, Perlindungan Konsumen Jasa Keuangan, L.N.R.I. Tahun 2013 No. 118 